\title{
STUDY OF THE STRENGTHENING AND TOUGHENING MECHANISM FOR SINGLE-CRYSTAL COPPER DURING EQUAL-CHANNEL ANGULAR PRESSING BY ROUTE A
}

\author{
ŠTUDIJA O MEHANIZMU KREPITVE IN KALJENJA MONO- \\ KRISTALINIČNEGA BAKRA MED POSTOPKOM ECAP PO POTI A
}

\author{
Ting-Biao Guo ${ }^{1,2 *}$, Shi-Ru Wei ${ }^{1}$, Qi $\mathrm{Li}^{1}$, Chen Wang ${ }^{1}$, Zhi Jia ${ }^{1,2}$, Yong $\mathrm{Hu}^{1,2}$, \\ Xing-Chang Tang 1,2 \\ ${ }^{1}$ Lanzhou University of Technology, State Key Laboratory of Advanced Processing and Recycling of Nonferrous Metals, \\ Lanzhou 730050, Gansu, China \\ ${ }^{2}$ Lanzhou University of Technology, Key Laboratory of Non-ferrous Metal Alloys and Processing, Ministry of Education, \\ Lanzhou 730050, Gansu, China
}

Prejem rokopisa - received: 2018-08-11; sprejem za objavo - accepted for publication: 2018-11-29

doi:10.17222/mit.2018.178

\begin{abstract}
Single-crystal copper has received more and more attention in the important areas of the national economy due to its good electrical and thermal conductivity and elongation. Its low strength limits its application, and so strengthening methods for single-crystal copper are of great concern. Therefore, we study the strengthening and toughening mechanisms of single-crystal copper by equal-channel angular pressing (ECAP). The single-crystal copper was processed by ECAP using route A with a die $\left(\Phi=105^{\circ}, \Psi=30^{\circ}\right)$. The microstructure and texture evolution were investigated by EBSD, XRD and SEM. The tensile properties were also tested. The results show that the ECAP method can improve the strength of materials without decreasing the conductivity. Under low strain, the crystal orientation still maintains the original orientation characteristics. As the strain increases, it forms numerous deformation bands with the same direction as the matrix. The texture-transformation process is $\{111\}<112>\rightarrow\{111\}<110>\rightarrow\{110\}<112>$ and $\{124\}<211>$. After 5 passes, the tensile strength increased from $168 \mathrm{MPa}$ to $435 \mathrm{MPa}$, and the elongation declined from $63 \%$ to $27.8 \%$. After 16 passes, the hardness increased from $60.4 \mathrm{HV}$ to $125 \mathrm{HV}$, while the conductivity remained at a high level of $95 \%$ IACS.

Keywords: single-crystal copper, equal-channel angular pressing, texture, mechanical properties
\end{abstract}

Monokristalinični baker postaja zaradi svoje dobre električne in toplotne prevodnosti ter duktilnosti vse bolj popularen material na pomembnih področjih nacionalnih ekonomij. Zaradi nekoliko manjše trdnosti je njegova uporabnost omejena. Ce želimo razširiti njegovo uporabnost, je razvoj novih metod njegovega utrjevanja zelo pomemben. Avtorji so raziskovali mehanizme utrjevanja in povečevanja žilavosti monokristaliničnega bakra s postopkom ECAP (iztiskovanjem pod kotom z enakim vhodom in izhodom matrice). Monokristalinični baker so obdelovali s postopkom ECAP z uporabo poti A, pri kateri ima orodje zunanji kot $\Phi=105^{\circ}$ in notranji kot $\Psi=30^{\circ}$. Razvoj mikrostrukture in teksture so raziskovali z EBSD, XRD in SEM. Prav tako so določili trdoto in mehanske lastnosti z nateznim preizkusom. Rezultati raziskav kažejo, da lahko postopek ECAP izboljša trdnost materiala brez poslabšanja prevodnosti. Pri majhnih deformacijah ostaja kristalna orientacija še vedno nespremenjena. S povečevanjem deformacije pa nastajajo številni deformacijski pasovi z enako orientacijo, kot jo ima matrica. Proces pretvorbe teksture poteka V smeri $\{111\}<112>\rightarrow\{111\}<110>\rightarrow\{110\}<112>$ in $\{124\}<211>$. Po 5 prehodih je natezna trdnost bakra narasla s $168 \mathrm{MPa}$ na $435 \mathrm{MPa}$ in raztezek je padel s $63,0 \%$ na 27,8 \%, električna prevodnost pa je še vedno ostala na visokem nivoju $95 \%$ IACS.

Ključne besede: monokristalinični baker, postopek ECAP (iztiskovanje pod kotom z enakim vhodom in izhodom matrice), tekstura, mehanske lastnosti

\section{INDRODUCTION}

Single-crystal copper has better conductivity and plasticity than polycrystalline copper, which is widely used in microelectronic devices, metal lead frames, communication network wires and so on. ${ }^{1,2}$ However, the lower strength severely limits its application in important fields. Thus the reinforcement methods of this material have attracted a lot of attention. ${ }^{3}$ The traditional method for improving the properties of metals is to alloy them with impurity elements to change their microstructure and phase constitution. ${ }^{4}$ For example, the addition of carbon and manganese makes steels harder, and alloying

*Corresponding author e-mail: guotb@1ut.cn steel with nickel and chromium makes it more resistant to corrosion. ${ }^{5}$ The strengthening of materials traditionally involves controlling the creation of internal defects and boundaries in order to obstruct dislocation motion, but defects also increase the scattering of conducting electrons. In other words, methods conducted to strengthen metals generally also cause an obvious decrease in the electrical conductivity. ${ }^{6,7}$ Therefore, a tradeoff must be made between conductivity and mechanical strength.

An alternative approach involves the incorporation of interfaces into the crystalline lattice to improve the metal's properties without changing its chemical composition. ${ }^{4}$ Severe plastic deformation (SPD) including accumulative roll bonding (ARB), ${ }^{8}$ high-pressure torsion 
$(\mathrm{HPT})^{9}$ and equal channel angular pressing (ECAP) $)^{10,11}$ do not depend on alloy elements to improve the material properties, which can effectively control the crystal defects such as dislocations, grain boundaries and vacancies to strengthen materials in the process of deformation. However, the instability of the defects can also lead to a modification of the material properties during application. ${ }^{4}$ Many investigations have shown ${ }^{12-15}$ that the electrical resistivity of twin boundaries (TBs), which can block dislocation motion as a special kind of coherent boundary, is about one order of magnitude lower than that of the common high-angle grain boundaries (GB). Therefore, the metal containing a high density of TBs could effectively be strengthened without losing its high electrical conductivity. Lu found that high-purity $\mathrm{Cu}$ foil samples with high density nanometer scaled twins synthesized by means of a pulsed electro-deposition technique possesses a tensile strength of $1068 \mathrm{MPa}$, which is about 10 times higher than that of conventional coarse-grained copper, while retaining an electrical conductivity comparable to that of pure copper (97\% IACS). ${ }^{16}$ ECAP can achieve controllable transformation of the microstructure through forming oriented shear bands and high density TBs, by strictly controlling the deformation pattern, can improve the material and maintain its excellent performance. ${ }^{17-19} \mathrm{Lu}$ found that a nano-twin matrix lamellae structure can significantly increase a material's strength and it has little effect on a material's plasticity and conductivity. ${ }^{20} \mathrm{Xu}$ found that ultrafine grain (UFG) pure copper with a bimodal structure is obtained and the tensile strength was sharply improved after ECAP through 12 passes. ${ }^{21}$ Therefore, starting from the structural characteristics of a material, it is an important task of modern material science to control the microstructure to give full play to their potential performance through technological methods. The goal of this paper is to study the strengthening and toughening of single-crystal copper after ECAP using a $105^{\circ}$ die on route $\mathrm{A}$.

\section{EXPERIMENTAL PART}

Single-crystal copper rods having a diameter of 16.0 $\mathrm{mm}$ and length of $80 \mathrm{~mm}$ were prepared with a purity of $99.999 \%$ by Ohno Continue Casting (OCC). The samples were processed by ECAP at room temperature using a die with an internal angle $(\Phi)$ of $105^{\circ}$ and an outer corner angle $(\Psi)$ of $30^{\circ}$ at the point of intersection, as shown in Figure 1. The die was mounted on a YT100 four-column press. The analytically effective strain per pass is $\sim 0.8$. The billets were processed from 1 to 5 passes using the route A and each of the billets was kept at the same direction between each pass. For ECAP processing, all the billets were coated with a mixture of molybdenum disulfide $\left(\mathrm{MoS}_{2}\right)$ and oil as a lubricant.

Following the ECAP processing, the samples for microstructural examination were prepared by slicing the
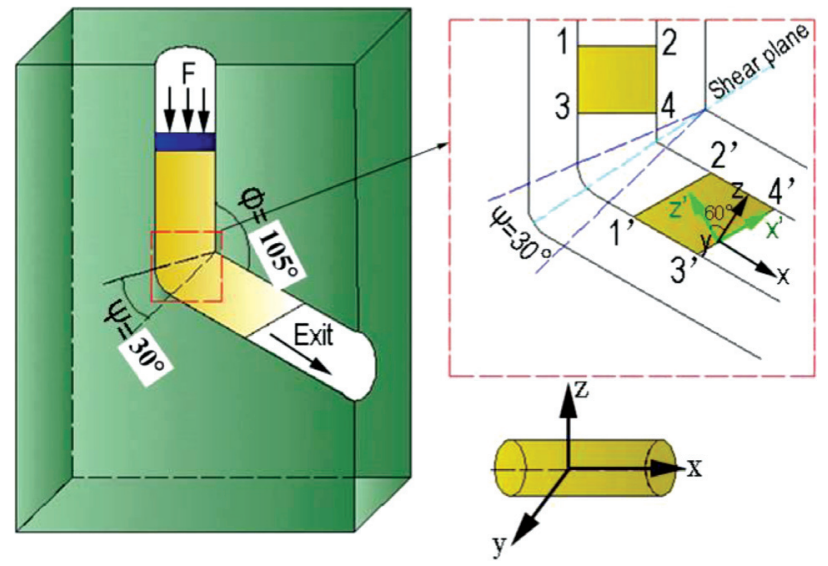

Figure 1: Schematic illustration of the principle of ECAP processing

billets perpendicular to the extrusion direction into 2.0-mm-thick slices, and then mechanically polished until a mirror-like surface was achieved. Finally, those slices were electro-polished for 6-8 $\mathrm{min}$ in a solution of $50 \%$ distilled water, $25 \%$ phosphoric acid, $25 \%$ alcohol using 4V. Electron-backscatter diffraction (EBSD) measurements were taken using a high-resolution scanning electron microscope (SEM) of Quanta FEG-450 equipped with a field-emission cathode. The EBSD maps were obtained by the HKL (Oxford Instruments) Channel5 software package. The X-ray diffractometer (XRD) measurements were performed using a D8 ADVANCE diffractometer to test the macroscopic grain orientation evolution. Finally, the tensile tests were conducted on an AG-10TA universal electronic tensile testing machine, and the Vickers hardness was also measured. The electrical conductivity was measured using a Sigma2008B/C digital electrical instrument.

\section{RESULTS AND DISCUSSION}

\subsection{Microstructure Evolution}

Figure 2 shows the microstructure of single-crystal copper in the initial condition and after ECAP with 1, 2 and 4 passes by route A. The scanning step was $0.2 \mu \mathrm{m}$ for the EBSD measurement, and different colors represent different crystal orientations. An inspection of Figure 2a indicates that single-crystal copper in the as-unpressed condition shows an obvious o crystal orientation. As shown in Figure 2b, tiny deformation structures are formed in the grain after 1 pass, which produces a significant contrast difference from the matrix. An inspection of Figure 2c shows that the first two passes of ECAP processing introduce large quantities of irregularity arrays of grains within the single crystal, and the matrix remains in the o orientation. After 4 passes, as shown in Figure 2d, the deformation bands having a consistent direction with a slight contrast difference from the matrix are formed. It indicates that the ECAP processing could significantly affect the distribution of stress in the sample, which leads to grain 


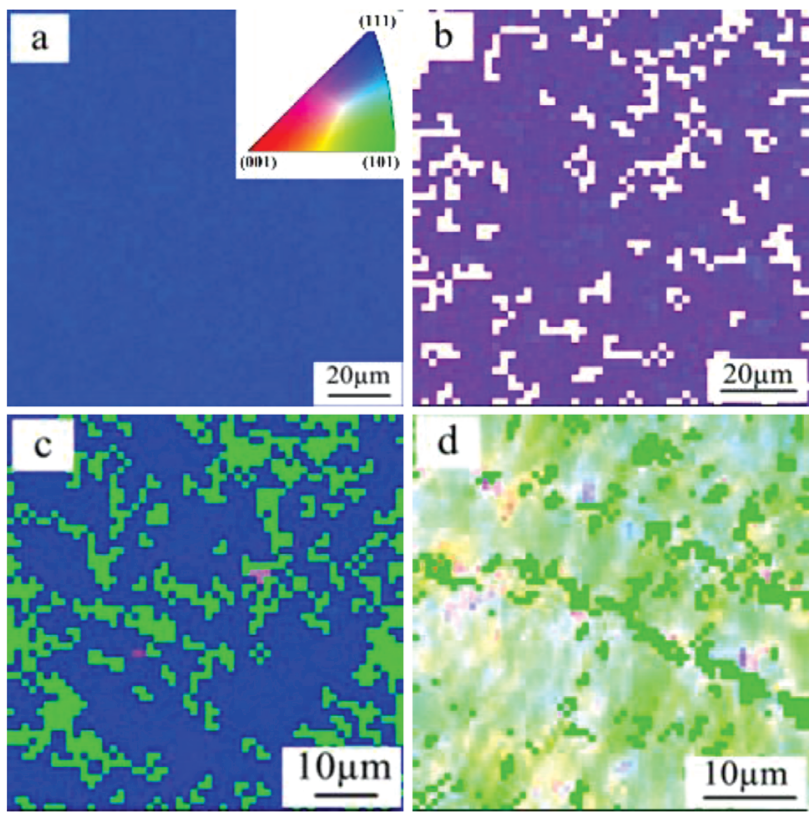

Figure 2: Orientation imaging microscopy (OIM) images for single-crystal copper in a) the initial condition and after ECAP through b) 1, c) 2 and d) 4 passes by route A
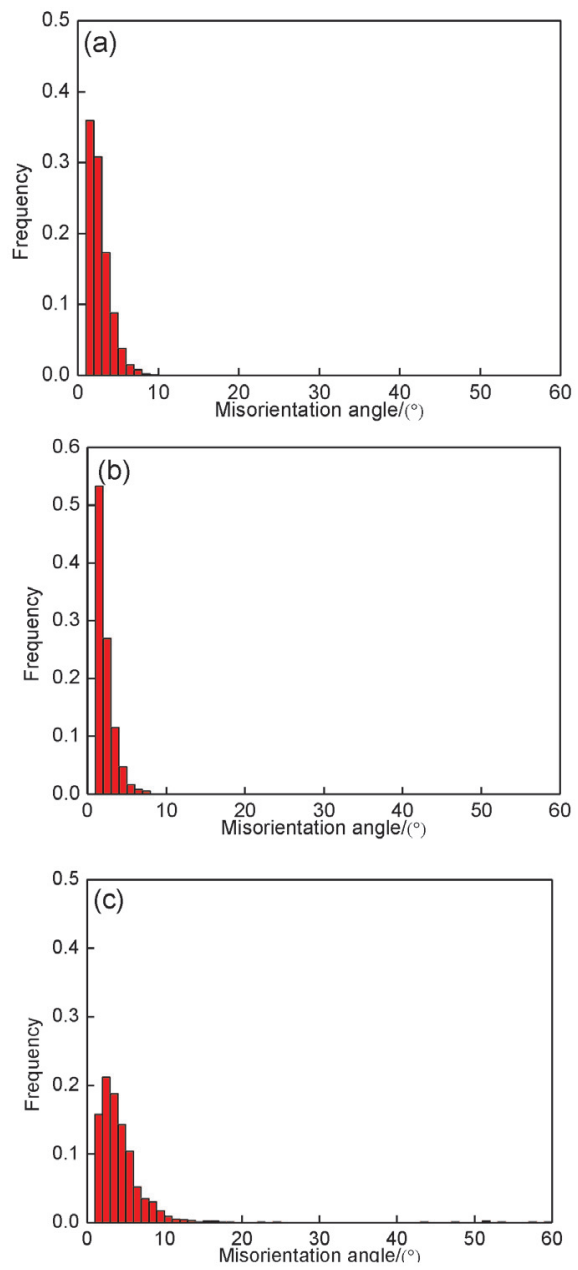

Figure 3: Misorientation distributions of single crystal copper after ECAP processing through a) 1, b) 2, and c) 4 passes by route A interiors forming new atom groups. These independent and continuous enlarging atom groups, i.e., grains, were consistent with the press axis direction and constituted a band-shaped structure. This is very similar to the studies of $\mathrm{Wu}$ and Guo. ${ }^{22,23}$

Figure 3 indicates the misorientation distributions after ECAP through 1, 2, and 4 passes. It can be seen from Figure 3a and $\mathbf{3 b}$ that a large amount of low-angle grain boundaries (LAGBs) are formed after 2 passes, which is due to the segmentation of the dislocations introduced by low-strain deformation. With increasing of the strain (shown in Figure 3c), the fraction of LAGBs slightly decreases, while the fraction of LAGBs for 10-20 degrees increases significantly, which is related to an increased amount of newly formed grains. We found that the proliferation and entanglement of dislocations leads to the formation of dislocation cells, resulting in a large increase in LAGBs during the early stages of deformation. This result shows that the original of the single crystal still keeps maintains quite a strong orientation characteristic. During the ECAP processing, low strain could not make the orientation characteristic of the original single crystal change sharply. Comparing the EBSD microstructures with four passes ECAP, the deformation bands structure in the single crystal shows an obvious orientation characteristic, gradually forming a strong texture in the single crystal.

\subsection{Texture Evolution}

\subsubsection{Grain orientation}

Figure 4 presents the XRD spectra of single-crystal copper in the initial condition and after ECAP processing with 1, 2 and 4 passes. An inspection of Figure 4 shows that the diffraction intensity of (111) for the original single-crystal copper is strong, which indicates an obvious preferred orientation. After 1 pass, the diffraction intensity increases significantly at the peak (220), and the (111) peak decreases slightly. With the increase

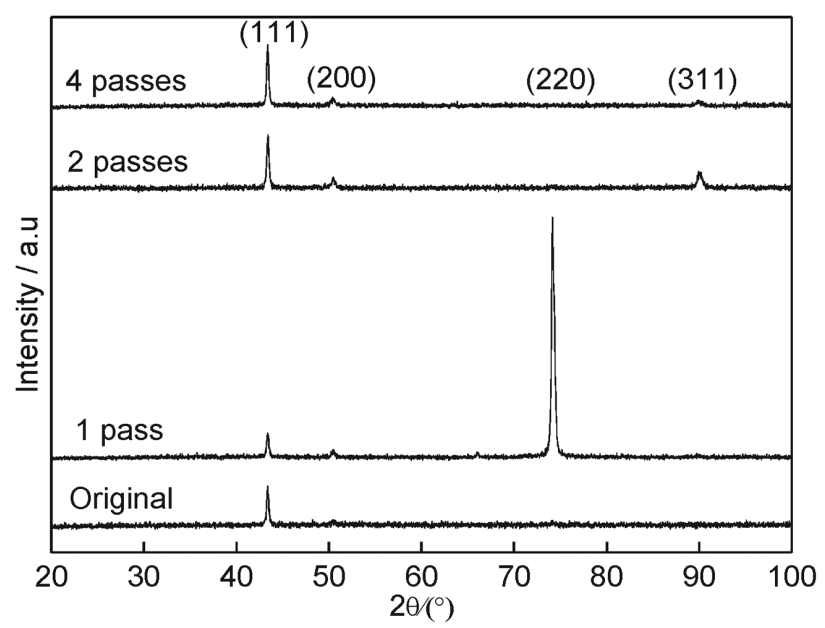

Figure 4: XRD spectra of single-crystal copper in a) the initial condition and after ECAP processing through b) 1, c) 2 and d) 4 passes 
of ECAP passes the (111) peak increases gradually, and the peak corresponding to the crystallographic planes with a large Miller index (311) also gradually increases. Thus, it can be seen that the transformation process of the preferential orientation for single-crystal copper is $(111) \rightarrow(220) \rightarrow(111)$ crystal face during ECAP.

We found that a different deformation pattern has a significant effect on the grains orientation during ECAP processing. Previous studies have shown that it leads to a typical multi-system slipping were activated for route Bc that the billet is rotated by $90^{\circ}$ in the same direction between consecutive passes, for which the grain orientation from the (111) preferred orientation changed to random orientation through the $\mathrm{Bc}$ route after 4 passes deformation for the directional solidification of pure copper. For the route $\mathrm{A}$, where the billet is not rotated between consecutive passes, and the main sliding systems are activated, the sliding is always towards to the (111) faces. In addition, the energy of the (111) crystal surface is lower than that of the other crystal surfaces in the FCC structure. Therefore, the crystal orientation is distributed as much as possible on the lower energy (111) crystal face during ECAP.

Figure 5 shows the pole figures during ECAP through 1, 2 and 4 passes. ND represents the normal (perpendicular to extrusion direction), while ED represents the extrusion direction. It can be seen the gauss oriented characteristic from initial pole figure and the maximum pole density is 18.34 (shown in Figure 5a). With increasing of the ECAP passes, the gauss oriented turns around the $\mathrm{o}$ axis and the maximum pole density decreased gradually, as shown in Figure $\mathbf{5 b}$ and $\mathbf{5 c}$. Inspection of Figure 5d illustrates that the gauss
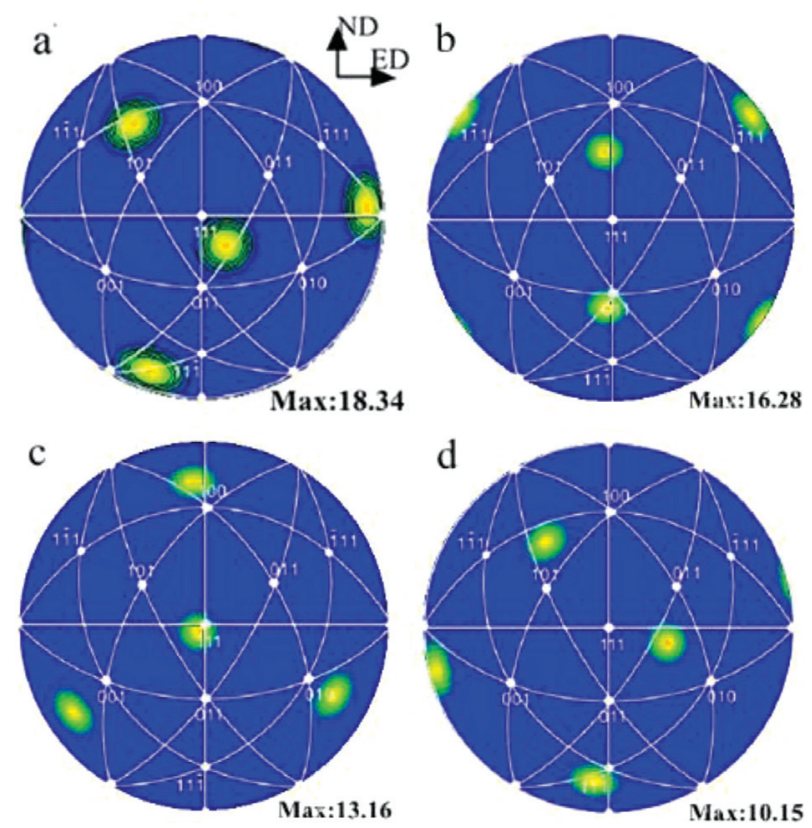

Figure 5: Pole figures of single-crystal copper in a) the initial condition and after ECAP processing through b) 1, c) 2 and d) 4 passes using route $\mathrm{A}$ oriented is transformed into the cube orientation after 4 passes.

The pole figures show that the orientation dispersion almost does not occur after 4 passes, it means they still maintain the characteristics of single-crystal copper. This result suggests that the single-crystal structure is not broken and formed the same oriented deformation band as shown in Figure 2d, which is consistent with the results of Wu's studies. ${ }^{23}$

\subsubsection{ODF analyzed}

Figure 6 shows the orientation distribution function (ODF) sections of single-crystal copper in the initial condition and after ECAP through 1, 2 and 4 passes. It can be seen from the $45^{\circ}$ section map in Figure 6a that the original single-crystal copper has a strong $\{111\}<112>$ texture. As shown in Figure $\mathbf{6 b}$ and $\mathbf{6 c}$, the $\{111\}$ p texture transformed into $\{111\} \mathrm{n}$ texture without new texture style generating after 1 and 2 passes. An inspection of Figure $\mathbf{6 d}$ shows that the $\{111\}$ n texture has disappeared, the $\{110\}<112>$ and $\{124\} \breve{S}$ texture was formed and it also can be seen from this figure that there is both a significant decrease in intensity of the texture after 4 passes and no change in the original texture of the single-crystal copper at the low strain. With an increasing of the strain, the texture intensity gradually decreases. This means the shear characteristics were presented on the same shear plane along the same shear direction by route A. At the same time, the same oriented shear bands were formed. Therefore, it is difficult to change the texture type at the early stage of deformation. Research shows that the direction of the perpendicular to the die diagonal plane is the second shear stress direction. ${ }^{24}$ In the later stage of deformation, enough plastic strain will be accumulated along this
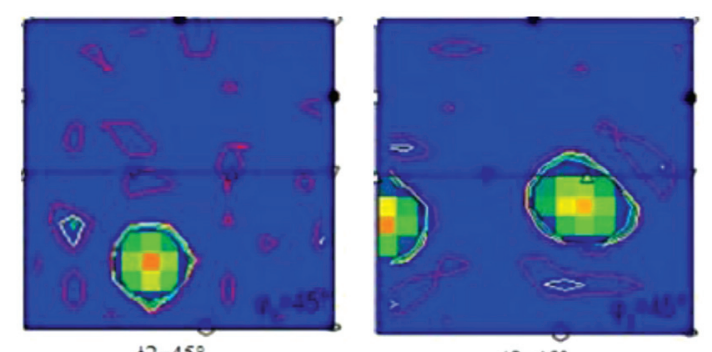

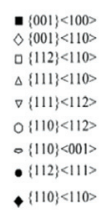
$\phi 2=45^{\circ}$
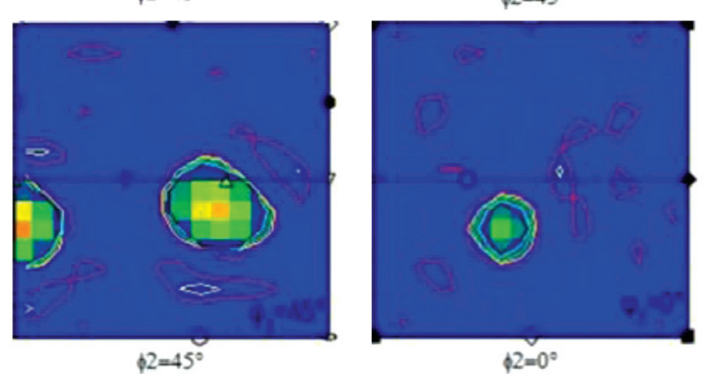

Figure 6: Orientation distribution function (ODF) sections of singlecrystal copper in a) the initial condition and after ECAP through b) 1 , c) 2 and d) 4 passes 
direction, which leads to the shear bands fractured and a large number of the atomic group that has an orientation different from the deformation bands was growing, resulting in the texture intensity decreasing and tending to be uniform.

\subsection{Mechanical properties and electrical conductivity}

Figure 7 shows the tensile strength and elongation of single-crystal copper subjected to different extrusion passes. The tensile strength of the original single-crystal copper is $168 \mathrm{MPa}$, the elongation is $63 \%$. After 2 passes, the tensile strength increased greatly to $365 \mathrm{MPa}$, while the elongation decreased greatly to $24.9 \%$. With increasing of the strain, the elongation slightly rebounded. After 5 passes, the tensile strength and elongation were $435 \mathrm{MPa}$ and $27.8 \%$, respectively. Figure 8 indicates the hardness of the single-crystal copper during ECAP processing through 1 to 16 passes. It can be seen that the hardness of the original single-crystal copper is $60.8 \mathrm{HV}$, and increased rapidly to $100.2 \mathrm{HV}$ after 1 pass. In the later stage of deformation, the hardness tended to be stable. After 16 passes, the hardness increased to 125 HV.

When studying the strain-hardening behavior of single-crystal copper during ECAP, according to the formula:

$$
\varepsilon_{\mathrm{N}}=\frac{N}{\sqrt{3}}\left\{2 \cot \left(\frac{\phi}{2}+\frac{\varphi}{2}\right)+\varphi \csc \left(\frac{\phi}{2}+\frac{\varphi}{2}\right)\right\}
$$

where $\varepsilon_{\mathrm{N}}$ is the strain, $N$ is the ECAP pass, and $\phi, \varphi$ is the inner angle and an outer corner angle, respectively. The effective strain per pass that is calculated as $\sim 0.8$ increased to $\sim 4.0$ in the material through the die channel of $105^{\circ}$ after 5 passes. ${ }^{25}$ Under the lower strain, it can produce high-density dislocations and an amount of sub-boundaries that hinder the movement of dislocations, for which single-rystal copper shows the obvious strain-hardening behavior and the elongation decreases sharply during ECAP processing. With increasing of the

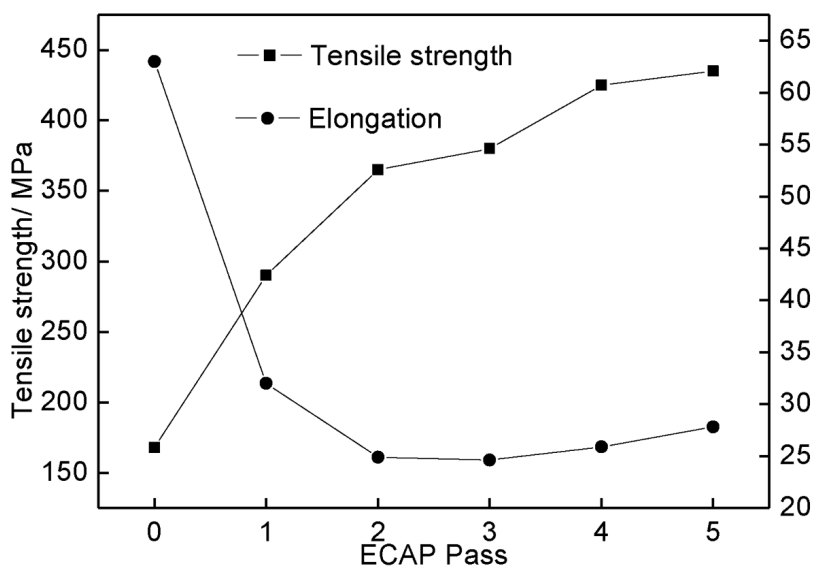

Figure 7: Elongation and tensile strength of single-crystal copper during ECAP through 1 to 5 passes

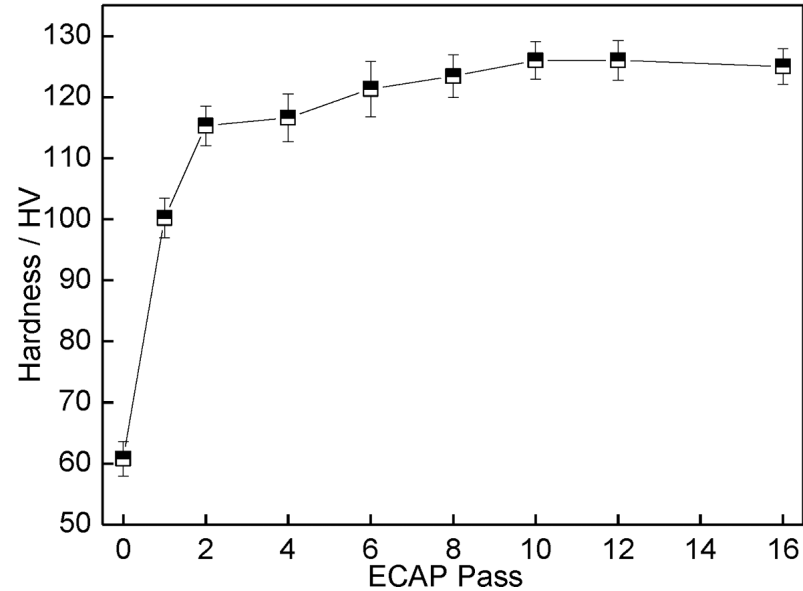

Figure 8: Hardness of single-crystal copper during ECAP through 1 to 5 passes

strain, there exists a local dynamic recovery and dynamic recrystallization for single-crystal copper, which leads to a small amount of dislocations disappearing. In addition, a large number of grain boundaries and subboundaries have been produced during ECAP processing, and the grain boundaries can act as an effective dislocation source and play a particularly important role in coordinating the plastic deformation. ${ }^{26,27}$ As a result, the elongation increases slightly. After 8 passes, a large number of sub-boundaries are formed and grown into large-angle grain boundaries by absorption and recombination dislocation, meanwhile, the strengthening effect of defects on materials reaches the limit with increasing of the strain, which leads to the growth of hardness that was slow. Whereas, local dynamic recovery and dynamic recrystallization leads to lots of dislocations disappeared, therefore the hardness decreases slightly after 12 passes.

Figure 9 shows the electrical conductivity of singlecrystal copper during ECAP through 1 to 16 passes. It drops to $97.3 \%$ IACS after 2 passes that the conductivity of the original single crystal copper is $100.8 \%$ IACS, and in the subsequent deformation processing, it grad-

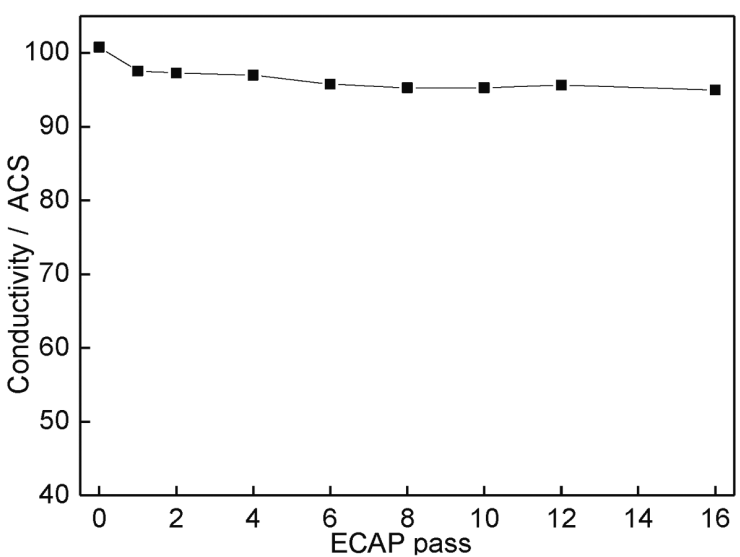

Figure 9: Electrical conductivity of single-crystal copper during ECAP through 1 to 16 passes 

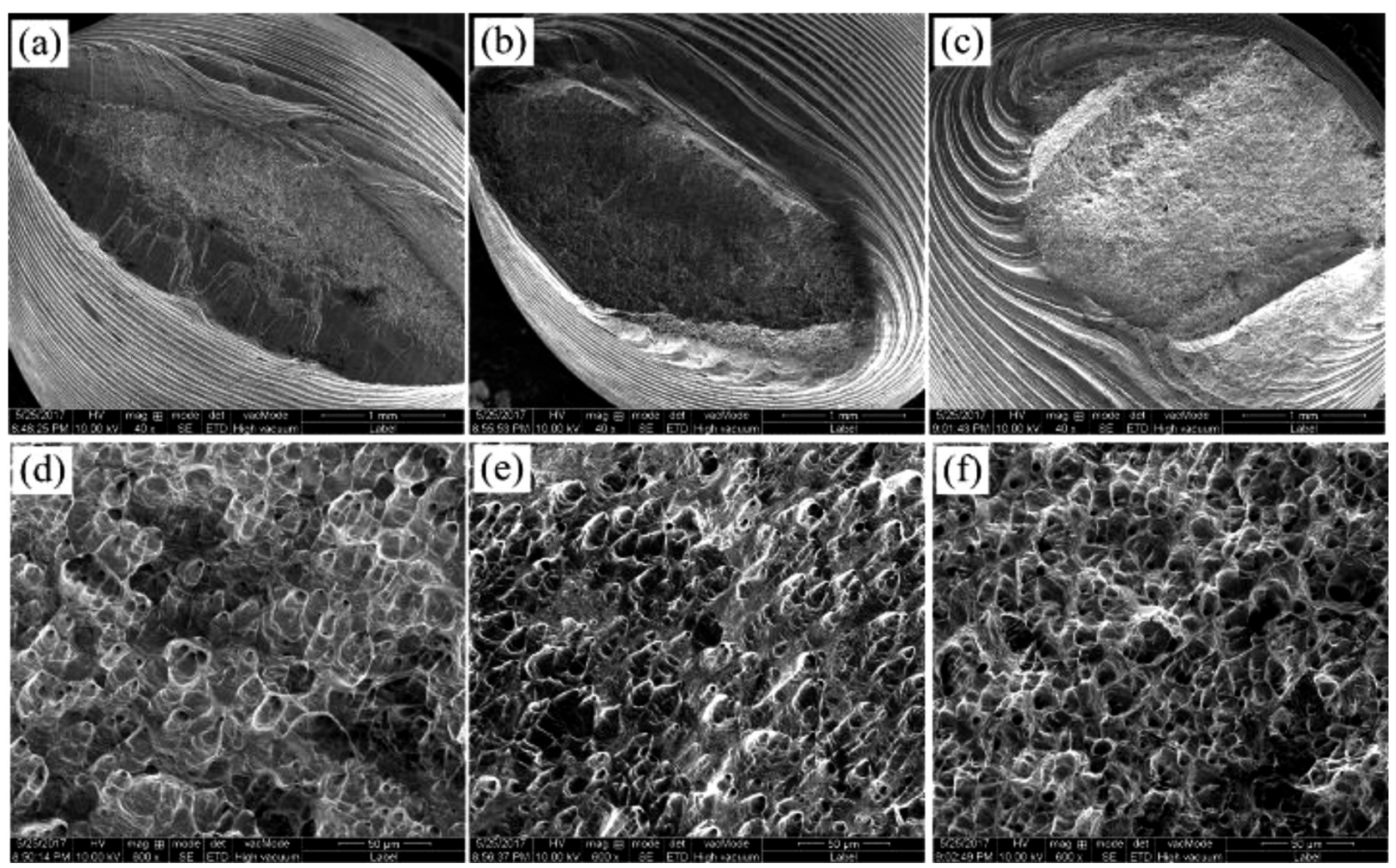

Figure 10: Macroscopic and micro-morphology tensile fractured morphologies after ECAP through 1, 3, and 5 passes

ually tends to be stable, but there will be slight fluctuations. We concluded that a large number of sub-boundaries and more dislocations are formed in the single-crystal copper at the early deformation stage, at the same time, the sub-boundaries and the defects in the material increased the electron scattering slightly in the electron transport process, which leads to a slight decrease in the conductivity of single-crystal copper. In general, ECAP can greatly improve the strength of the material and have little effect on the electrical conductivity.

Figure 10 presents the macroscopic and micro-morphology tensile fractured morphologies after ECAP through 1, 3, and 5 passes. Inspection of Figure 11a shows macroscopic tensile fractured morphologies are both flat and tip with obvious characteristics of ductile fracture after 1 pass. With the increase of ECAP strain, the area of fractured morphologies increased gradually, as shown in Figures 11b and 11c. It means that the plasticity reduced gradually. It can be seen from the micromorphology tensile fractured morphologies that an amount of sub-boundaries leads to resistance increasing of the crack propagation, the density and uniformity of dimples increase sharply with the strain increase as shown in Figure 11d to 11f, and its depth tends to be consistent. However, it is still a ductile fracture.

\section{CONCLUSIONS}

1) The original single-crystal copper shows a strong o crystal orientation. After 4 passes, textured deformation bands with a small contrast difference were formed in the matrix, with increased the amount of low-angle grain boundaries (LAGBs).

2) The texture transformation process is $\{111\}<112>$ $\rightarrow\{111\}<110>\rightarrow\{110\}<112>$ and $\{124\}<211>$ during ECAP, and the texture intensity was gradually weakened, but still maintained the orientation characteristics of a single crystal.

3) After 2 passes, the tensile strength increased from $168 \mathrm{MPa}$ to $365 \mathrm{MPa}$, the hardness increased from $60.8 \mathrm{HV}$ to $115.3 \mathrm{HV}$, while the elongation decreased from $63 \%$ to $24.9 \%$. The tensile strength, hardness and elongation became stable with increasing of the strain. After 5 passes, the tensile strength and elongation were $435 \mathrm{MPa}$ and $27.8 \%$, respectively.

4) The ECAP method does not depend on alloying elements to strengthen the material, and can effectively control the crystal defects of the single-crystal matrix to form an ordered grain-boundary structure, in order to improve the material properties. And more importantly, it has less influence on the electrical conductivity. 


\section{Acknowledgements}

This research was financially supported by the National Natural Science Foundation of China (no. 51261016) and the Natural Science Foundation of Gansu Province, China (no. 1212RJZA027).

\section{REFERENCES}

${ }^{1}$ Y. Fukuda, K. Oh-Ishi, M. Furkkawa, Z. Horita, T. G. Langdon, Influence of crystal orientation on the processing of copper single crystals by ECAP, J. Mater. Sci, 42 (2007) 5, 1501-1511

${ }^{2}$ Y. T. Ding, G. J. Xu, F.W. Guo, S. Z. Kou, Y. F. Lan, Z. F.Ding, G. L. Liu, C. L. Feng, X. S. Yang, Properties of single crystal copper produced by heated mould continious casting, Chin. J. Nonferrous. Met, 12 (2003) 5, 1071-1076, doi:10.19476/j.ysxb.1004.0609.2003. 05.004

${ }^{3}$ S. X. Qu, H. F. Zhou, Mechanical behaviors and deformation mechanisms of nover nano-structured metals, Adv. Mech, 44 (2014) 1, 338-375, doi:10.6052/1000-0992-14-046

${ }^{4} \mathrm{~K}$. Lu, Stabilizing nanostructures in metals using grain and twin boundary architectures, Nat. Rev. Mater, 1 (2016) 5, 1-13, doi:10.1038/natrevmats.2016.19

${ }^{5}$ R. W. Cahn, P. Haasen, E. J. Kramer, Materials Science and Technology - A Comprehensive Treatment: Index of Volume, Mater. Sci. Eng. A, 199 (1995), 245-247, doi:10.1002/9783527619313

${ }^{6}$ K. Lu, L. Lu, S. Suresh, Strengthening materials by engineering coherent internal boundaries at the nanoscale, Science, 324 (2009) 5929, 349-352, doi:10.1126/science. 1159610

${ }^{7}$ X. Y. Li, K. Lu, Playing with defects in metals, Nat. Mater, 16 (2017) 7, 700-701, doi:10.1038/nmat4929

${ }^{8}$ N. Takata, S. H. Lee, N. Tsuji, Ultrafine grained copper alloy sheets having both high strength and high electric conductivity, Mater Lett, 63 (2009) 21, 1757-1760, doi:10.1016/j.matlet.2009.05.021

${ }^{9}$ S. V. Dobatkin, J. Gubicza, D. V. Shangina, N. R. Bochvar, N. Y. Tabachkova, High strength and good electrical conductivity in $\mathrm{Cu}-\mathrm{Cr}$ alloys processed by severe plastic deformation, Mater. Lett, 153 (2015), 5-9, doi:10.1016/j.matlet.2015.03.144

${ }^{10}$ Y. Fukuda, K. Oh-ishi, M. Furukawa, Z. Horita, T. G. Langdon, Influence of crystal orientation on ECAP of aluminum single crystals, Mater. Sci. Eng. A, 420 (2006) 1, 79-86, doi:10.1016/ j.msea.2006.01.086

${ }^{11}$ S. D. Wu, Z. G. Wang, C. B. Jiang, G. Y. Li, I. V. Alexandrov, R. Z. Valiev, Shear bands in cyclically deformed ultrafine grained copper processed by ECAP, Mater. Sci. Eng. A, 387 (2004) 6, 560-564, doi:10.1016/j.msea.2003.12.087

${ }^{12}$ Y. S. Li, N. R. Tao, K. Lu, Microstructural evolution and nanostructure formation in copper during dynamic plastic deformation at cryogenic temperatures, Acta. Mater, 56 (2008) 2, 230-241, doi:10.1016/j.actamat.2007.09.020

${ }^{13}$ X. C. Liu, H. W. Zhang, K. Lu, Strain-induced ultrahard and ultrastable nanolaminated structure in nickel, Science, 342 (2013) 6156, 337-340, doi:10.1126/science. 1242578
${ }^{14}$ A. Hasnaoui, H. V. Swygenhoven, P. M. Derlet, On non-equilibrium grain boundaries and their effect on thermal and mechanical behaviour: a molecular dynamics computer simulation, Acta. Mater, 50 (2002) 15, 3927-3939, doi:10.1016/S1359-6454(02)00195-7

${ }^{15}$ L. Lu, Y. Shen, X. Chen, L. Qian, K. Lu, Ultrahigh strength and high electrical conductivity in copper, Science, 304 (2004) 5669, 422-426, doi:10.1126/science. 1092905

${ }^{16} \mathrm{~K}$. Lu, A study on ultrahigh strength and high electrical conductivity in copper, Bull. Chin. Academy. Sci, 19 (2004) 5, 422-426, doi:10.16418/j.issn.1000-3045.2004.05.008

${ }^{17}$ S. D. Wu, Z. G. Wang, C. B. Jiang, G. Y. Li, I. V. Alexandrov, R. Z. Valiev, The formation of PSB-like shear bands in cyclically deformed ultrafine grained copper processed by ECAP, Scr. Mater, 48 (2003) 12, 1605-1609, doi:10.1016/S1359-6462(03)00141-6

${ }^{18}$ N. R. Tao, K. Lu, Preparation techniques for nanostructured metallic materials via plastic deformation, Acta. Metall. Sin, 50 (2014), 141-147, doi:10.3724/SP.J.1037.2013.00803

${ }^{19}$ T. B. Guo, Q. Li, C. Wang, F. Zhang, Z. Jia, Deformation characteristics and mechanical properties of single crystal copper during equal channel angular pressing by route A, Acta. Metall. Sin, 53 (2017) 8, 991-1000, doi:10.11900/0412.1961.2016.00582

${ }^{20} \mathrm{~L}$. Lu, K. Lu, Metallic materials with nano-scale twins, Acta. Metall. Sin, 46 (2010) 11, 1422-1427, doi:10.3724/SP.J.1037.2010.00462

${ }^{21}$ J. Xu, J. W. Li, D. B. Shan, B. Guo, Microstructural evolution and micro/meso-deformation behavior in pure copper processed by equal-channel angular pressing, Mater. Sci. Eng. A, 664 (2016), 114-125, doi:10.1016/j.msea.2016.03.016

${ }^{22}$ S. D. Wu, X. H. An, W. Z. Han, S. Qu, Z. F. Zhang, Microstructure evolution and mechanical properties of fcc metallic materials subjected to equal channel angular pressing, Acta. Metall. Sin, 46 (2010) 3, 257-276, doi:10.3724/SP.J.1037.2009.00748

${ }^{23}$ T. Guo, Y. Ding, X. Yuan, Y. Hu, Microstructure and orientation evolution of unidirectional solidification pure copper during ECAP, Rare. Metal. Mat. Eng, 40 (2011) s3, 171-175

${ }^{24}$ W. Z. Han, Z. F. Zhang, S. D. Wu, S. X. Li, Influences of crystallographic orientations on deformation mechanism and grain refinement of Al single crystals subjected to one-pass equal-channel angular pressing, Acta. Mater, 55 (2007) 17, 5889-5900, doi:10.1016/ j.actamat.2007.07.008

${ }^{25}$ S. Ferrasse, V. M. Segal, S. R. Kalidindi, F. Alford, Texture evolution during equal channel angular extrusion: Part I, Effect of route, number of passes and initial texture, Mater. Sci. Eng. A, 368 (2004) 1, 28-40, doi:10.1016/j.msea.2003.09.077

${ }^{26}$ V. Yamakov, D. Wolf, M. Salazar, S. R. Phillpot, H. Gleiter, Lengthscale effects in the nucleation of extended dislocations in nanocrystalline Al by molecular-dynamics simulation, Acta. Mater, 49 (2001) 14, 2713-2722, doi:10.1016/S1359-6454(01)00167-7

${ }^{27}$ X. H. An, S. D. Wu, Z. F. Zhang, Influence of stacking fault energy on the microstructures, tensile and fatigue properties of nanostructured Cu-Al alloys, Acta. Metall. Sin, 50 (2014) 2, 191-201, doi:10.3724/SP.J.1037.2013.00 